University of Nebraska - Lincoln

DigitalCommons@University of Nebraska - Lincoln

1998

\title{
Efficacy of Maxforce Bait for Control of the Argentine Ant (Hymenoptera: Formicidae) in Haleakala National Park, Maui, Hawaii
}

\author{
Paul D. Krushelnycky \\ U.S. Geological Survey/Biological Resources Division, Haleakala National Park Field Station, Box 369, \\ Makawao, HI 96768
}

Neil J. Reimerz

Hawaii Department of Agriculture, 701 Ilalo Street, Honolulu, HI 96813

Follow this and additional works at: https://digitalcommons.unl.edu/entomologyother

Part of the Entomology Commons

Krushelnycky, Paul D. and Reimerz, Neil J., "Efficacy of Maxforce Bait for Control of the Argentine Ant (Hymenoptera: Formicidae) in Haleakala National Park, Maui, Hawaii" (1998). Entomology Papers from Other Sources. 80.

https://digitalcommons.unl.edu/entomologyother/80

This Article is brought to you for free and open access by the Entomology Collections, Miscellaneous at DigitalCommons@University of Nebraska - Lincoln. It has been accepted for inclusion in Entomology Papers from Other Sources by an authorized administrator of DigitalCommons@University of Nebraska - Lincoln. 


\title{
Efficacy of Maxforce Bait for Control of the Argentine Ant (Hymenoptera: Formicidae) in Haleakala National Park, Maui, Hawaii
}

\author{
PAUL D. KRUSHELNYCKY ${ }^{1}$ AND NEIL J. REIMER 2
}

\begin{abstract}
Environ. Entomol. 27(6): 1473-1481 (1998)
ABSTRACT In an effort to develop a chemical control strategy for the invasive Argentine ant, Linepithema humile (Mayr), in Haleakala National Park, Maxforce, which is formulated with $0.9 \%$ hydramethylnon, was used in test plots to determine the efficacy of the ant bait in the field. Initially, Maxforce was tested at 2 application rates: broadcast at $2.25 \mathrm{~kg} / \mathrm{ha}(2 \mathrm{lb} /$ acre $)$ and $4.5 \mathrm{~kg} / \mathrm{ha}(4$ $\mathrm{lb} /$ acre). Later, the following treatments were also tested: a Maxforce and honey granule mix, Maxforce with $0.5 \%$ hydramethylnon, Maxforce with a different solvent, Maxforce distributed in exposed piles, and Maxforce distributed in covered piles. Although there were significant differences in the magnitude of ant reduction among the various treatments, all yielded the same general result. Foraging ant numbers at monitoring bait stations declined an average maximum of $97.0 \%$ in the test plots, with no plots achieving $100 \%$ reduction. At 2 mo after treatment the mean number of foraging ants was reduced by $92.1 \%$. Nest survival in the plots appeared to be affected to a lesser degree, but could not be monitored accurately over the longer term because of the phenomenon of nest movement. A 2nd identical application 1 mo after the initial application in plots treated with Maxforce at 2.25 and $4.5 \mathrm{~kg} / \mathrm{ha}$ did not result in eradication. Bait molding, quick mortality, and toxicant breakdown from UV radiation created a short exposure time to the bait and toxicant, which may have been the main obstacle to achieving eradication.
\end{abstract}

KEY WORDS Linepithema humile, Maxforce, Hawaii, biological invasion, alien species

The Hawallan Islands are devoid of endemic ants (Wilson and Taylor 1967). The native fauna of this extremely isolated island chain are not adapted to the particular pressures exerted by aggressive ant predation (Gillespie and Reimer 1993). As a result, the highly vulnerable native arthropods have been heavily affected by ant species introduced over the past $200 \mathrm{yr}$ (Cole et al. 1992, Perkins 1913). Although $\approx 44$ ant species have naturalized in the Hawaiian Islands, most have become established at low elevations, severely depleting the native lowland fauna. The Argentine ant, Linepithema humile (Mayr), however, has been able to thrive at higher elevations, invading largely intact natural areas such as Haleakala National Park on Maui (Cole et al. 1992).

The Argentine ant is an aggressive, polygynous tramp species that forms large, dense colonies, and has become an agricultural and ecological pest in various areas of the world (Erickson 1971, Ward 1987, Tremper 1976, Bond and Slingsby 1984). In Haleakala National Park, Cole et al. (1992) demonstrated the effects of the ant's presence and predation on the native arthropod fauna. They predicted that this could have a significant impact on native plant reproduction, as some of the affected insects are major pollinators of native plants. Since 1st recorded in the park in 1967

${ }^{1}$ U.S. Geological Survey/Biological Resources Division, Haleakala National Park Field Station, Box 369, Makawao, HI 96768.

${ }^{2}$ Hawaii Department of Agriculture, 701 Ilalo Street. Honolulu, HI 96813.
(Huddleston and Fluker 1968), the Argentine ant has steadily expanded its range, despite extreme, quickly changing climatic conditions. As of 1996, 2 distinct populations of the ant occupy $\approx 455$ ha on the upper western slopes and crater walls of Haleakala volcano. Based on observations of habitat already occupied by L. humile, much of the park's crater would seem to be suitable for its survival and colonization (Fellers and Fellers 1982).

Because of the persistent advance of the Argentine ant in Haleakala National Park, the Research Division (now a unit of the Biological Resources Division of the USGS) began investigating a control strategy for the pest. Biological control was not considered feasible, therefore a program addressing toxicants as a possible method for control was initiated. Tests of the efficacy of hydramethylnon against the Argentine ant in California citrus groves by Gaston and Baker (1984) used the toxicant suspended in a $25 \%$ sugar water solution and found a 40 -fold reduction in ant numbers on tree trunks. Additionally, Forschler and Evans (1994) found that commercially formulated Maxforce (hydramethylnon in a silkworm high-protein bait) was attractive to and effective against the Argentine ant in urban situations in Georgia. A highly attractive bait formulated with a slow acting toxicant such as hydramethylnon might also prove to be effective against the Argentine ant in Haleakala.

Previously, eradication of the introduced ant Wasmannia auropunctata (Roger) was achieved on Santa Fe Island in the Galapagos using the bait Amdro 
(American Cynamid Co., Wayne, NJ), a corn-grit granular bait with hydramethylnon as the active ingredient (Abedrabbo 1994). Although this control effort also took place in a natural area, the size of the infestation, estimated at 2-3 ha, was considerably smaller than the one at Haleakala. Also, the corn-grit/ soybean oil bait carrier of Amdro is unattractive to the Argentine ant at Haleakala (unpublished data). To determine the best bait carrier for toxicant control, a year-long bait preference test was conducted at Haleakala National Park in 1994-1995 (unpublished data). The toxicant-free bait carrier for the commercial ant bait Maxforce, produced by the Clorox Company (Pleasanton, CA), was found to be the most attractive among 6 solid baits tested. In addition, the granular formulation allows for easy dispersal on a large scale.

The size of the infested areas and the terrain at Haleakala present some logistical challenges for treatment. Aerial broadcast of the bait is the most feasible, if not the only possible solution. Accordingly, the lst efficacy tests presented here were specifically designed to test the effects of a single (or possibly 2) broadcast treatment of Maxforce granular ant bait in field conditions at Haleakala. Eradication was the explicit goal; however, we realized that this would be unlikely because of the fact that most ant control strategies involve prolonged exposure to the bait and toxicant to achieve success. Past successes with eradication of bigheaded ant, Pheidole megacephala (F.), from 1.4-ha plots (Reimer and Beardsley 1990), however, encouraged us to attempt this economical approach before moving on to more costly strategies that might involve repeated treatments or more permanent bait stations.

\section{Materials and Methods}

Initial Test. Maxforce granular bait with $0.9 \%$ hydramethylnon was first tested in July of 1995 at 2 application rates: $2.25 \mathrm{~kg} / \mathrm{ha}(2 \mathrm{lb} /$ acre $)$ and $4.5 \mathrm{~kg} / \mathrm{ha}$ ( $4 \mathrm{lb} /$ acre). Each rate was tested with 3 replicate test plots. Test plots were 25 by $25 \mathrm{~m}$, separated by at least $15-20 \mathrm{~m}$, and were placed within a high ant density area in typical subalpine shrubland at $2,200 \mathrm{~m}$ elevation in the lower ant population. This small plot size was chosen for ease of treatment and monitoring. Long-term monitoring was not a goal, and it was felt that short-term results would not be influenced by movement of nests into the plots from outside. Three replicate control plots, which received no treatment, were established adjacent to the test plots at a distance of $25-50 \mathrm{~m}$.

Pretreatment ant counts were conducted in all 9 plots to establish baseline ant numbers. Five bait monitoring stations were placed in the center of each plot, separated by $\approx 2 \mathrm{~m}$. Monitoring stations consisted of a $4-\mathrm{cm}^{2}$ patch of fermented fish paste siganid) placed on a 3 by 5 " index card. Total number of ants on the card was counted roughly $45 \mathrm{~min}$ after placement. Test plots were first treated on 16 July 1995 by walking through the plots and broadcasting the granular bait right up to the plot borders, using a standard "whirlybird" hand spreader. Plots were treated at dusk to minimize the bait's exposure to sunlight, as the active ingredient hydramethylnon degrades in UV radiation. Posttreatment ant counts were conducted every $2 \mathrm{~d}$ for $\approx 1.5 \mathrm{wk}$ and at less regular intervals subsequently.

Inspection of test plots $\approx 2 \mathrm{wk}$ after treatment yielded an unexpected finding: bait was found molding in nests under rocks, making it clearly visible. Otherwise, the small granules are impossible to distinguish from the soil and cinder. Taking advantage of this development, the 3 test plots treated at $4.5 \mathrm{~kg} / \mathrm{ha}$ were surveyed for bait distribution by the ants. Nests were located, that either had molding bait or were still active (defined as having either brood or a queen present) or both; 50 such nests were located by turning over rocks in 2 of the plots, and 43 in the $3 \mathrm{rd}$. Nests that had only workers visible and no bait were not counted, because it was impossible to determine whether the nest was dying from the treatment or whether it had moved the brood, queens, and the majority of the workers before treatment. For each nest, information was recorded regarding the relative amount of visible bait, as well as whether the nest was active or inactive (defined as having no brood and no queens).

Subsequent Tests. Maxforce test plots were treated a 2nd time on 19 August 1995 at the original application rates. Ant counts at bait stations continued to be used as a means of measuring ant numbers in the plots. Five additional plots were established to test the following treatments, all distributed at a rate of $4.5 \mathrm{~kg} / \mathrm{ha}$ : a mix of 1 half Maxforce granules and 1 half honey granules; Maxforce granules formulated with $0.5 \%$ hydramethylnon; Maxforce granules formulated with $0.5 \%$ hydramethylnon and a different solvent; Maxforce granules distributed in 25 equal piles (by weight), uncovered; and Maxforce granules distributed in 25 equal piles, covered with inverted pie pans. In these last 2 plots, the piles were evenly spaced $5 \mathrm{~m}$ apart in a grid. The first 3 plots were treated on 24 August 1995 and the Maxforce piles were distributed in the last 2 plots on 12 September 1995.

Ant counts using bait monitoring stations were recorded to assess ant numbers in the 5 aforementioned plots. Nest surveys to detect bait distribution were conducted as previously described $2-2.5 \mathrm{wk}$ after treatment in the 3 plots using broadcast treatment (not piles). Ant count data were normalized by $\log _{10}(x+1)$ transformation and analyzed using an $F$ test to check for homogeneity of variances. Treatments with similar variances were then tested with either a 1-way or 2-way analysis of variance (ANOVA), depending on whether the treatments had replicate plots. Means were subsequently compared with a Tukey test for equal sample sizes or a TukeyKramer test for unequal sample sizes (Sokal and Rohlf 1981). Nest observation data were analyzed using a chi-square contingency table. 
Table 1. Mean number of ants per monitoring station after treatment, averaged over the length of the study

\begin{tabular}{|c|c|c|c|}
\hline 1 & Maxforce at $4.5 \mathrm{~kg} / \mathrm{ha}$ & $2.59 \pm 0.18 \mathrm{a}$ & 85 \\
\hline 2 & Maxforce at $2.25 \mathrm{~kg} / \mathrm{ha}$ & $2.07 \pm 0.16 \mathrm{~b}$ & 85 \\
\hline 4 & Maxforce with $0.5 \%$ hydramethylnon & $2.50 \pm 0.24 \mathrm{f}, \mathrm{g}$ & 40 \\
\hline 5 & Maxforce with $0.5 \%$ hydramethylnon and a different solvent at $4.5 \mathrm{~kg} / \mathrm{ha}$ & $1.25 \pm 0.18 \mathrm{~d}, \mathrm{e}$ & 40 \\
\hline 6 & Maxforce at $4.5 \mathrm{~kg} / \mathrm{ha}$ in 25 equal piles, uncovered & $1.60 \pm 0.22 \mathrm{e}, \mathrm{f}$ & 25 \\
\hline 7 & Maxforce at $4.5 \mathrm{~kg} / \mathrm{ha}$ in 25 equal piles, covered & $2.64 \pm 0.42 \mathrm{f}, \mathrm{g}$ & 25 \\
\hline Control & No treatment & $8.80 \pm 0.48 \mathrm{c}$ & 105 \\
\hline
\end{tabular}

Means followed by the same letter are not significantly different $(P<0.05)$. $n$, Total number of monitoring station counts

\section{Results}

Ant Counts. The average numbers of ants per station after treatment in the test plots were low, regardless of treatment (Table 1). However, an $F$ test on the $\log _{10}(x+1)$-transformed data indicated that the ant count data for treatments 1,2 , and the control had significantly different variance $(P=0.05)$ compared with the count data for treatments 3-7 (Table 1). These 2 groups of treatments were therefore analyzed separately.

A 2-way ANOVA (replicate plots and treatments) showed that for treatments 1,2 (Maxforce at $4.5 \mathrm{~kg} / \mathrm{ha}$ and Maxforce at $2.25 \mathrm{~kg} / \mathrm{ha}$ ), and control, there was no significant difference among the 3 replicates of each $(F=2.91 ; \mathrm{df}=2,801 ; P>0.05)$. However, differences between the 2 treatments compared with the control were highly significant $(F=205.68 ; \mathrm{df}=2,801 ; P<$ 0.001 )

Comparison of treatments 3-7 using a 1-way ANOVA showed that there were significant differences among these treatments $(F=5.84 ; \mathrm{df}=4,165$; $P<0.001)$. Separation of means with a Tukey test for equal sample sizes and a Tukey-Kramer test for unequal sample sizes revealed that treatment 5 (mix of Maxforce and honey granules) was different from both treatment 4 (Maxforce with $0.5 \%$ hydramethylnon) and treatment 7 (Maxforce distributed in covered piles). All other treatments were not significantly different from each other (Table 1).

All treatments, except for the control, exhibited the same general pattern: relatively high ant levels before treatment and a dramatic crash within several days after treatment (Figs. 1-3). This crash can be quantified as an average of a $95.9 \%$ reduction in mean number of ants per monitoring station in all plots $2 \mathrm{~d}$ after treatment. The maximum average reduction in number of ants in all plots reached $97.0 \%$. In plots treated with Maxforce at 2.25 and $4.5 \mathrm{~kg} / \mathrm{ha}$, ant counts slowly increased to a $70.0 \%$ reduction (5-7 ants per station) until they were treated again $34 \mathrm{~d}$ after the 1st treatment (Fig. 1). All plots treated with scattered granular bait (not in piles) averaged a retention of $92.1 \%$ reduction 2 mo after the latest treatment (Figs. 1 and 2). Control plots had an average reduction of $48.3 \%$ in the mean number of ants per monitoring station over the length of the study (Figs. 1-3).

Nest Surveys. Approximately $2 \mathrm{wk}$ after treatment $\approx 44-76 \%$ of all surveyed nests were still active in plots treated with various formulations of Maxforce (Table 2 ). As a consequence of the bait molding, it was possible to determine that $27-72 \%$ of all nests surveyed had visible signs of bait retrieval in plots treated with the various formulations of Maxforce we tested (Fig. 4). However, not all nests that retrieved baits became inactive. As shown in Figs. 4 and $9-44 \%$ of all active nests contained bait in plots treated with the various formulations.

After the plots originally treated with Maxforce at $4.5 \mathrm{~kg} / \mathrm{ha}$ were treated a $2 \mathrm{nd}$ time at the same rate, $23 \%$ of all the surveyed nests remained active (Table 2 ). These active nests constituted $46.5 \%$ of the originally active nests in the plots.

\section{Discussion}

Foraging Ant Numbers. Results of the efficacy tests indicated that treatment with Maxforce was followed by a reduction in foraging ant numbers. Monitoring of ant numbers using ant counts at bait monitoring stations provided a good method for estimating relative foraging levels in the plots. With this technique, it was possible to detect a dramatic crash in foraging ant numbers as early as $2 \mathrm{~d}$ after treatment (Figs. 1-3). The maximum reduction in forager numbers averaged $97.0 \%$ for all treatments, and all plots treated with broadcast granular bait (not in piles) averaged a retention of $92.1 \%$ reduction in foraging ant numbers 2 mo after treatment.

Treatments 1 and 2 (Maxforce at $4.5 \mathrm{~kg} / \mathrm{ha}$ and Maxforce at $2.25 \mathrm{~kg} / \mathrm{ha}$, respectively) were the central focus of the study because they used commercially available Maxforce distributed by a broadcast method. The remaining 5 treatments were implemented as secondary efforts after it appeared that the first 2 were not achieving eradication. Three of the additional 5 treatments were specially formulated for these tests by the Clorox Company and are not commercially available. The remaining 2 treatments used commercial Maxforce, but the granules were distributed in carefully weighed and spaced piles, a method not practical on a large scale.

Examination of the efficacy of these 5 additional treatments revealed that they resulted in similar reductions in foraging ant numbers at the monitoring stations (Table 1; Figs. 1-3). Although the average numbers of ants per station for these 5 treatments 


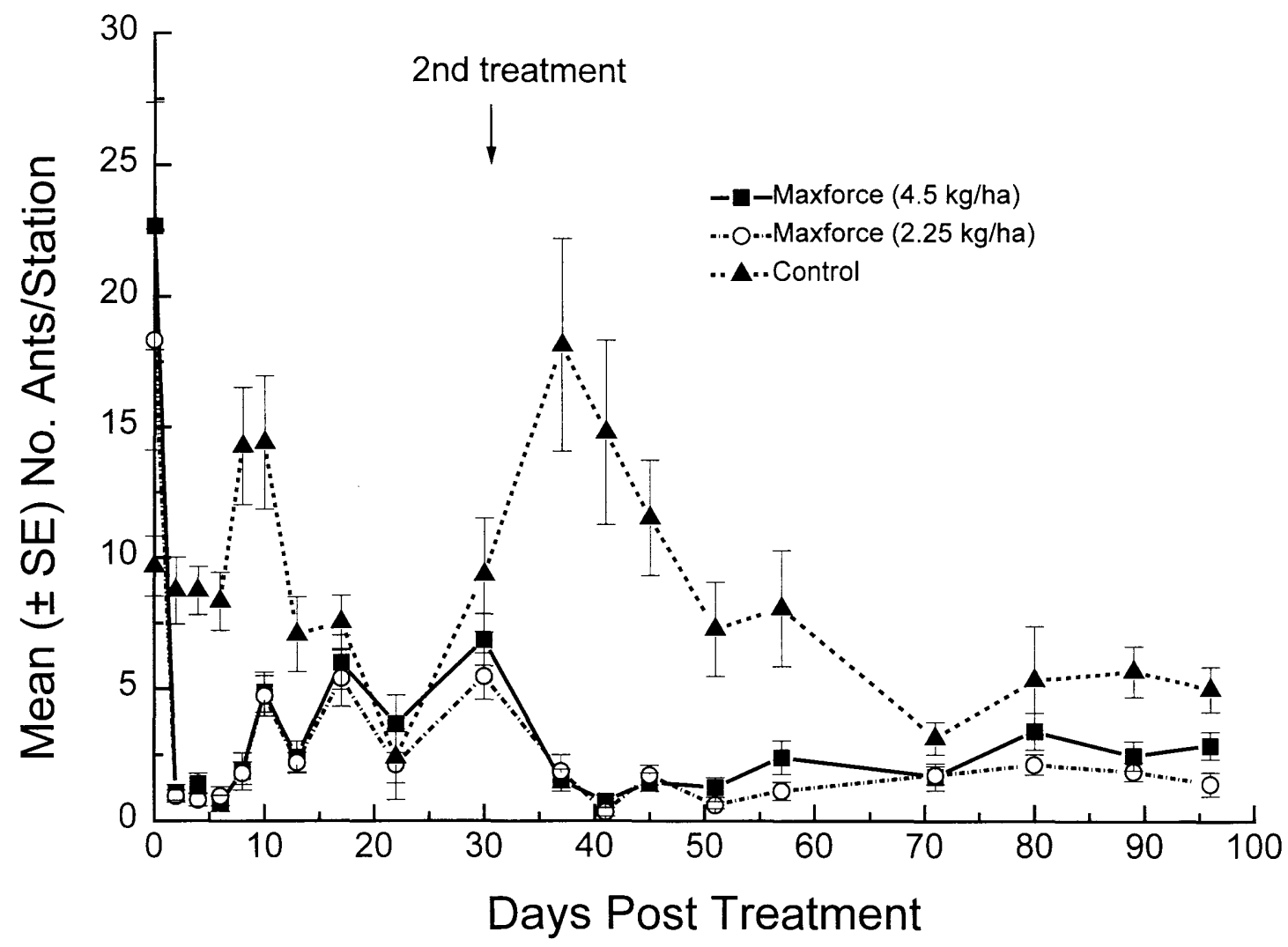

Fig. 1. Mean $\pm \mathrm{SE}$ numbers of ants per station over time in plots treated with Maxforce at $4.5 \mathrm{~kg} / \mathrm{ha}$, Maxforce at 2.25 $\mathrm{kg} / \mathrm{ha}$, and control.

were found to be statistically different from treatments 1 and 2 , much of this was due to large differences in sample size. And although treatment 5 (Maxforce with $0.5 \%$ hydramethylnon and a different solvent) yielded the lowest mean number of ants per station and was significantly different from treatments 4 and 7 , none of these 5 treatments resulted in 0 foraging ants at the bait monitoring stations. In light of the fact that a treatment of Maxforce with $0.5 \%$ hydramethylnon and a different solvent only produced an average of 1 less ant per monitoring station than a regular Maxforce treatment, it is doubtful that this and the other 4 secondary treatments would be worth their additional manufacturing costs when used on a large scale.

Based on a study testing the control of bigheaded ants with Amdro (another bait using hydramethylnon as the active ingredient) it was judged that control of the Argentine ants in the test plots should be achieved in 7-10 d (Reimer and Beardsley 1990). After ant count numbers in plots treated with Maxforce at 2.25 and $4.5 \mathrm{~kg} / \mathrm{ha}$ had rebounded from a $95 \%$ reduction $2 \mathrm{~d}$ after treatment to a $70 \%$ reduction $34 \mathrm{~d}$ after treatment, it was decided to try a 2 nd application of the same treatments. Ant numbers at bait monitoring stations once again dropped (Fig. 1) and retained an $89.9 \%$ reduction 2 mo after the 2 nd treatment. The 2 nd treatment did not, however, succeed in yielding 0 foraging ants at monitoring stations.

Ultimately, analysis of the ant count data for plots treated with Maxforce at 4.5 and $2.25 \mathrm{~kg} / \mathrm{h}$ a found little difference in the results yielded by each. With this in mind, it is clear that there was no benefit gained from treating infested areas at the higher application rate, yet the cost was greater. In fact, application rates lower than $2.25 \mathrm{~kg} /$ ha should be tested in the future.

It should be noted that means of ant counts in control plots were substantially lower than in test plots before treatment, and decreased during the last $1.5 \mathrm{mo}$ of monitoring (Fig. 1). The initial discrepancy between foraging ant numbers in treated and control plots was simply a result of differences in local ant densities. Control plot locations were placed adjacent to the treated plots and appeared to be situated in similar habitat. In retrospect, however, the density of suitable nesting rocks looks to be less, and this may have been responsible for the lower numbers of ants at monitoring stations.

The decrease in recruitment to monitoring stations in the control plots in the latter half of the monitoring effort, amounting to a decline of $\approx 48 \%$, may have been a function of the ant's seasonal biology. Winter decreases in ant numbers should not have yet occurred at the end of monitoring in mid-October (unpublished 


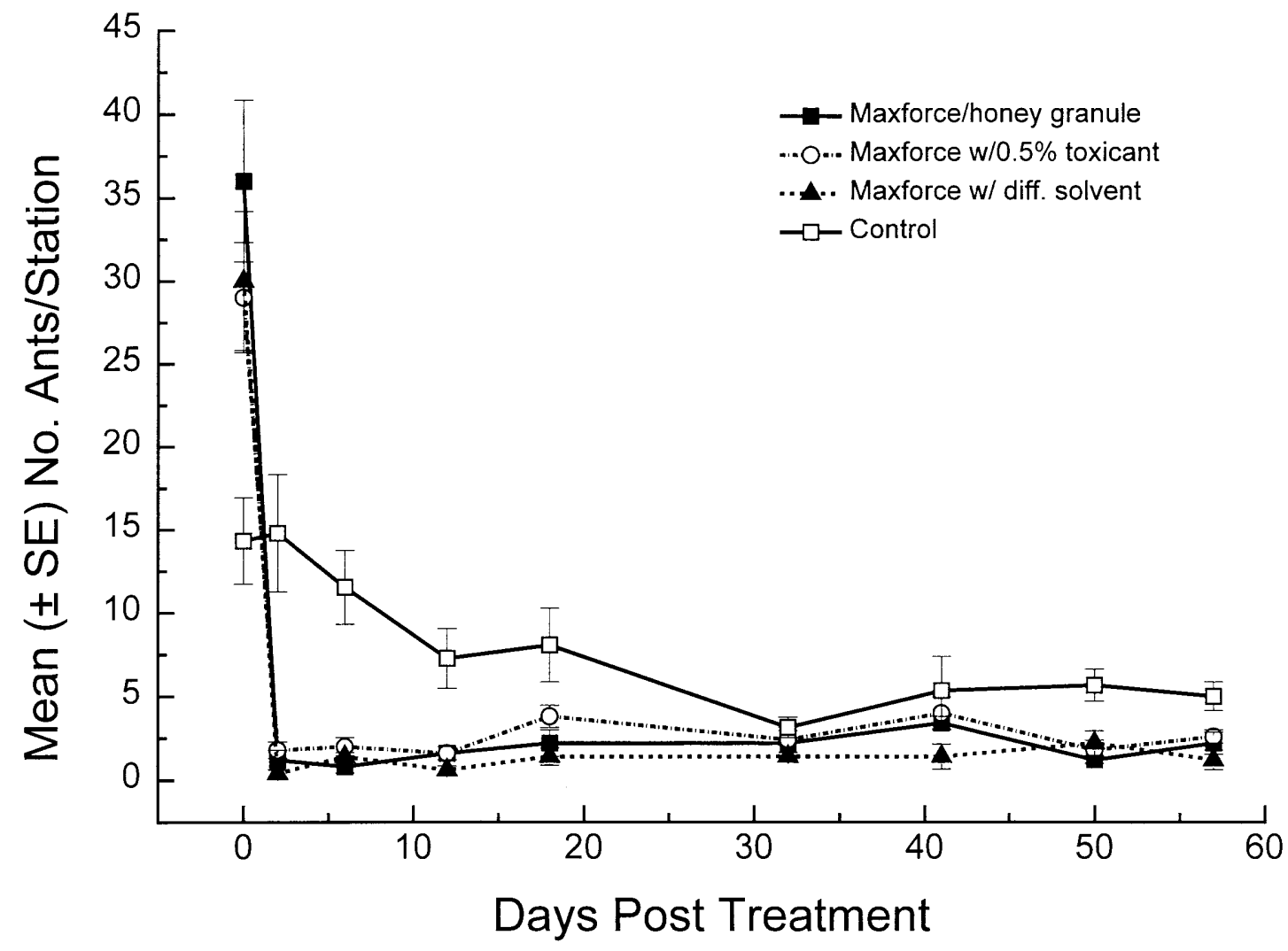

Fig. 2. Mean $\pm \mathrm{SE}$ numbers of ants per station over time in plots treated with a Maxforce/honey granule mix, Maxforce with $0.5 \%$ hydramethylnon, Maxforce with a different solvent, and control.

data). However, brood production probably had begun to decrease by this point, and perhaps the attractiveness of the blended fish bait used at the monitoring stations declined as high protein food sources became less important. The possibility of this reduction occurring as a consequence of the treatments in nearby test plots is unlikely because ant count numbers actually increased in the control plots soon after the treatments (Fig. 1). Although the ant count numbers in treated and control plots appear rather similar toward the end of the monitoring effort, there was still a significant difference between the means of posttreatment ant counts of treated and control plots for all treatments tested (Table 1).

Nest Survival. Although monitoring station ant count data documented a significant crash in foraging ant numbers after Maxforce treatment, this only represents a portion of the total ant populations in the test plots. Even with heavy recruitment of workers to the monitoring stations, a survey of this group alone is incomplete. In an unexpected development, molding of the Maxforce bait in the often damp conditions under rocks allowed it to be visible against an otherwise nearly identical soil and cinder ground surface. The mold therefore served as a sort of natural marker, often making it possible to trace distribution of bait to nests in the plots. Because of this discovery, nests in plots representing 4 of the treatments (Maxforce at 4.5 $\mathrm{kg} / \mathrm{ha}$, Maxforce and honey granule mix, Maxforce with $0.5 \%$ hydramethylnon, and Maxforce with a different solvent) were surveyed for activity and the visible presence of bait. Plots treated with Maxforce at $2.25 \mathrm{~kg} / \mathrm{ha}$ were not surveyed in this manner because ant counts showed the effects of treatment to be similar to Maxforce at $4.5 \mathrm{~kg} / \mathrm{ha}$.

Plots were first surveyed $\approx 2 \mathrm{wk}$ after treatment; therefore, it was not possible to recognize all nests that were active at the time of treatment. Only nests that had brood or queens present or had visible bait present at the time of the survey were counted as active. It was assumed that nests with bait present had been alive at the time of treatment and workers from these nests had retrieved the bait. Nests with workers present but no brood, queens, or bait were ignored because it was impossible to determine if the brood and queens in these nests had died or had merely moved before treatment. This has some implications on the interpretation of the results because it may have artificially inflated our measure of nest survival rates.

Nest surveys $16 \mathrm{~d}$ after treatment revealed that $\approx 50 \%$ of all surveyed nests treated with Maxforce at $4.5 \mathrm{~kg}$ / ha were still active (Table 2 ). The rest were inactive, indicating that they had died or moved. 


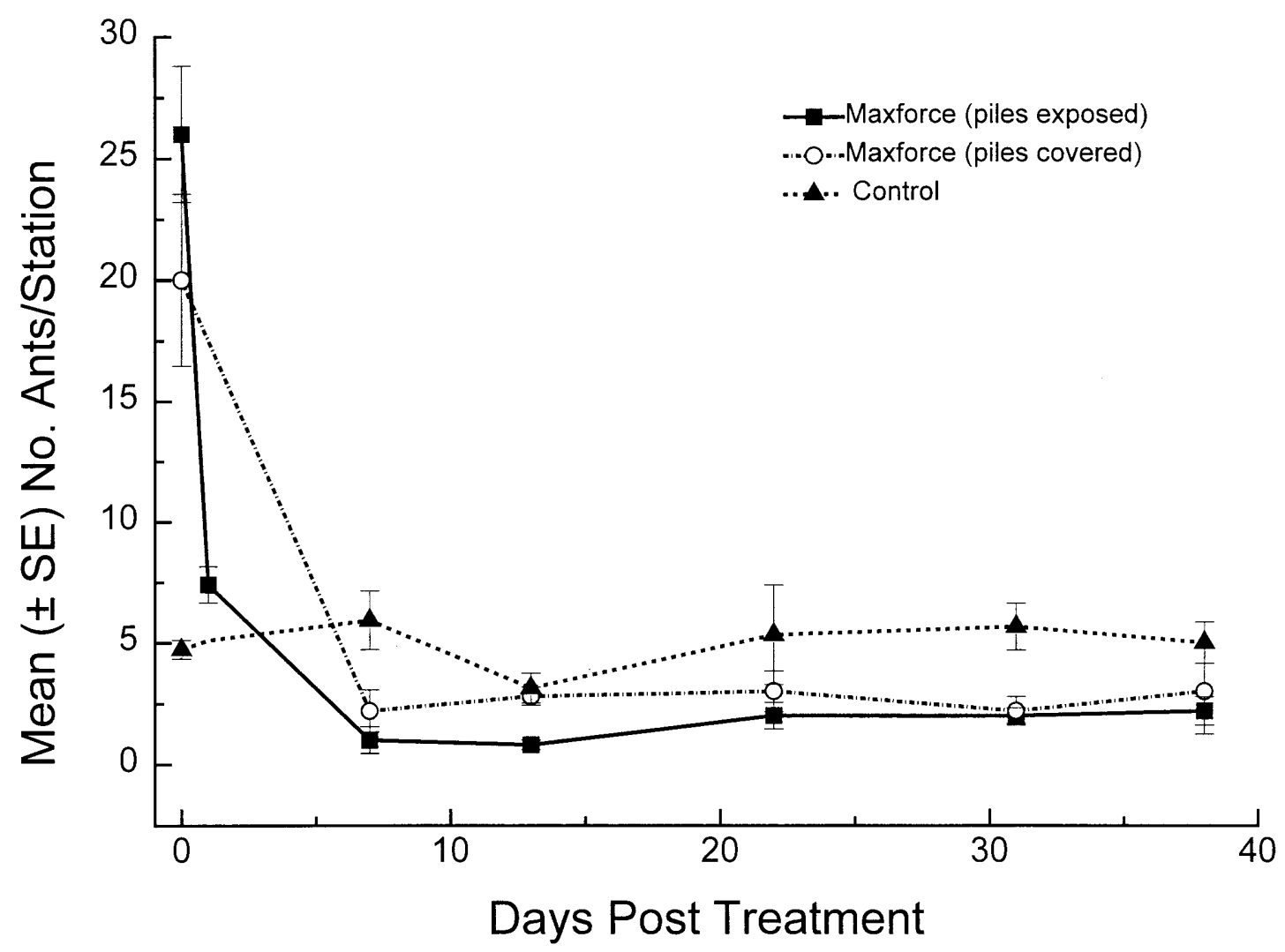

Fig. 3. Mean $\pm S E$ numbers of ants per station over time in plots treated with exposed piles of Maxforce, covered piles of Maxforce, and control.

Twelve days after the 2 nd treatment of Maxforce at 4.5 $\mathrm{kg} / \mathrm{ha}$, only $23 \%$ of all surveyed nests were still active. It is unclear whether this decrease occurred as a result of additional nest mortality from the 2 nd treatment or as a result of nest movement caused by disturbance from the 1st nest survey, or a combination of the 2 . Because Argentine ants at Haleakala nest under rocks, it is not difficult for them to shift to a new rock and construct a suitable nest. This behavior has been observed frequently, and the disturbance caused by our repeated lifting of the nest rocks in the course of the nest surveys alone may have been sufficient to prompt a move. Disturbance of this nature is the primary

Table 2. Nest survival in surveyed plots $\approx 2$ wk after treatment, measured as percent of surveyed nests active

\begin{tabular}{lcc}
\hline \multicolumn{1}{c}{ Treatment } & $\begin{array}{c}\text { Nest } \\
\text { survival, \% }\end{array}$ & $n$ \\
\hline Maxforce at $4.5 \mathrm{~kg} / \mathrm{ha}$ (1st application) & 49.6 & 51 \\
Maxforce and honey granule mix & 75.6 & 48 \\
Maxforce with 0.5\% (AI) & 44.0 & 50 \\
Maxforce with $0.5 \%$ (AI) and a different solvent & 44.0 & 50 \\
Maxforce at $4.5 \mathrm{~kg} / \mathrm{ha}$ (2nd application) & 23.1 & 51 \\
\hline
\end{tabular}

There were no significant differences in nest survival among the treatments $\left(\chi^{2}=2.0, \mathrm{df}=4, P>0.05\right) . n$, Number of nests. reason nest surveys were not conducted before treatment.

Nest surveys conducted $\approx 2 \mathrm{wk}$ after treatment in plots treated with the Maxforce and honey granule mix, Maxforce with 0. 5\% toxicant, and Maxforce formulated with a different solvent revealed that 76,44 , and $44 \%$ of all nests surveyed in these plots, respectively, were still active. Although it appears that in most plots (except the Maxforce and honey granule mix plot) at least $50 \%$ of the nests died soon after treatment, conclusions concerning nest survival after $2 \mathrm{wk}$ are confused by the potential phenomenon of nest movement.

The ant count data shows that the toxicant hydramethylnon caused mortality within $2 \mathrm{~d}$ after ingestion. Unfortunately, the bait and toxicant do not last much longer than this in the field. Exposed bait is quickly broken down by UV radiation (Vander Meer et al. 1982, Mallipudi et al. 1986), and more recent data has shown that the molding of Maxforce bait at Haleakala is visible as soon as $5 \mathrm{~d}$ after treatment and probably begins sooner (dependent on weather conditions). Bait protected from the sun under vegetation or drier underground conditions in nests may have lasted longer, but this seems unlikely. With these constraints in mind, it is doubtful that much if any mortality 
have been very similar if not identical to the results obtained in these small test plots (unpublished data). Foraging ant numbers recovered modestly in the centers of and throughout these large treated areas within a month and a half after treatment, indicating that some nests had survived.

We feel that eradication did not occur in these small test plots. However, the huge reduction in numbers of foraging ants was a good indication of what could be expected on a larger scale in mid- to late summer from a single (or 2) applications of the treatments tested. What then are the possible reasons for Maxforce's failure to eradicate the Argentine ant?

The even distribution of nests with molding bait indicated that the bait was well dispersed throughout the plots. Despite the good coverage, it appears that at least a certain number of the nests that retrieved bait did not die. For instance, in the commercially formulated and broadcast treated Maxforce plots, $43.7 \%$ of the nests found to still be active at $2 \mathrm{wk}$ after treatment had molding bait (Fig. 4). This survival can be attributed to 1 or a combination of several explanations.

First, the ants in these nests may have found the bait unattractive after the workers retrieved it, or may have detected some repellent qualities in the bait. However, repellency tests before treatment found regular Maxforce to have no detectable repellent qualities, and high rates of worker interchange and sharing between nests (Markin 1968) should rule out differential attractiveness among nests to a particular bait. Nevertheless, treatments with $0.5 \%$ active ingredient, a different solvent, and a honey granule mix were attempted in an effort to decrease repellency or increase bait attractiveness.

Smaller percentages of the active nests in these plots contained molding bait (Fig. 4), but nest survival rates (Table 2) and ant counts at monitoring stations (Figs. 1 and 2) were similar to those of the Maxforce treated plots. The exception is the Maxforce/honey granule mix plot, which had the highest nest survival rate and the lowest percentages of nests with molding bait, yet had worker ant counts similar to those in the other plots. It is possible that this bait, with a honey component, targeted mainly workers and was the least effective at targeting the queen and brood. Markin (1970) provided evidence for such a phenomenon.

Second, the surviving nests could have been distracted from the retrieved bait by competing, natural food sources. If highly attractive natural food sources, such as live or fresh insect larvae, were supplied to the nest at the same time as the treatment, it is possible that the bait would have received secondary priority, potentially molding before being used.

Third, the rates of bait consumption, mortality, and bait molding may have figured strongly into the failure to kill all nests. It has been suggested that because high rates of worker mortality occurred as quickly as $2 \mathrm{~d}$ after treatment, few workers remained to keep remaining bait caches free of microbes and mold. The main problem in this scenario is the inability of the entire nest to consume a lethal dose before high mortality and bait molding set in. This may be reduced somewhat by using a lower application rate, so that the reserve cache is smaller. However, it seems that the problem of short exposure time before mass mortality and bait molding would be most directly addressed by either slowing the action of the bait/toxicant or by applying repeated treatments. Maxforce formulated with $0.5 \%$ hydramethylnon instead of the commercial formulation of $0.9 \%$ did not succeed in slowing the rate of kill (Fig. 2), but repeated treatments may provide the increase in exposure time needed.

Forschler and Evans (1994) were able to achieve Argentine ant control using Maxforce in a lawn area of an apartment complex, but the ants in their study had extended access to Maxforce protected from the sun, and eradication of nests was accomplished only after replenishing the supply of bait over a period of $6 \mathrm{wk}$. In contrast, intense direct sun and extremely variable weather conditions at Haleakala produce a comparatively short window of opportunity for bait retrieval and consumption in which the half-life of exposed Maxforce is roughly $5 \mathrm{~d}$ and bait molding begins in a similar amount of time.

Future testing should therefore include baiting strategies that involve repeated treatments in larger plots, possibly at lower application rates and tested at different times of year. Investigation of multiple treatment strategies has been avoided until now because of the increase in cost for large scale use. It appears, however, that this type of approach may be necessary if eradication of the Argentine ant in Haleakala National Park remains a goal of park managers and scientists.

\section{Acknowledgments}

Art Medeiros (U. S. Geological Survey/Biological Resources Division [USGS/BRD]) and Lloyd Loope (USGS/ BRD) laid the groundwork for this study and brought concern about the Argentine ant's presence at Haleakala to the forefront. Their support and advice throughout the project was critical. Lisa Blum, Ted Shapas, and other staff at the Clorox Technical Center assisted in funding, provided Maxforce and other baits, and generously donated time and expertise to our efforts. We also thank Stephanie Joe (USGS/ BRD) for her assistance in field work and her input on study design, as well as Philip Thomas (USGS/BRD) for his help in database design and general computer assistance. Much advice and assistance was also provided in statistical analysis by Helen Baker, Anne Brasher, and Ellen Van Gelder while working at the USGS/BRD Haleakala National Park Field Station.

\section{References Cited}

Abedrabbo, S. 1994. Control of the little fire ant, Wasmannia auropunctata, on Santa Fe Island in the Galapagos Islands, pp. 219-227. In D. F. Williams [ed.], Exotic ants: biology, impact, and control of introduced species. Westview, Boulder, CO.

Bond, W., and P. Slingsby. 1984. Collapse of an ant-plant mutualism: the Argentine ant (Iridomyrmex humilis) and myrmecochorous proteaceae. Ecology 65: 1031-1037.

Cole, F. R., A. C. Medeiros, L. L. Loope, and W. W. Zuehlke. 1992. Effects of the Argentine ant on arthropod fauna of 
Hawaiian high-elevation shrubland. Ecology 73: 13131322.

Erickson, J. M. 1971. The displacement of native ant species by the introduced Argentine ant Iridomyrmex humilis Mayr. Psyche 78: 257-266.

Fellers, J. H., and G. M. Fellers. 1982. Status and distribution of ants in the Crater District of Haleakala National Park Pac. Sci. 36: 427-437.

Forschler, B. T., and G. M. Evans. 1994. Argentine ant (Hymenoptera: Formicidae) foraging activity response to selected containerized baits. J. Entomol. Sci. 29: 209-214.

Gaston, L. K., and T. C. Baker. 1984. Toxic bait to control Argentine ant field tested. Citrograph 69: 188.

Gillespie, R. G., and N. Reimer. 1993. The effect of alien predatory ants (Hymenoptera: Formicidae) on Hawaiian endemic spiders (Araneae: Tetragnathidae). Pac. Sci. 47: 21-33.

Huddleston, E. W., and S. Fluker. 1968. Distribution of ants species of Hawaii. Proc. Hawaii. Entomol. Soc. 20: 45-69.

Mallipudi, N. M., S. J. Stout, A. Lee, and E. J. Orloski. 1986. Photolysis of Amdro fire ant insecticide active ingredient hydramethylnon (AC 217,300) in distilled water. J. Agric. Food Chem. 34: 1050-1057.

Markin, G. P. 1968. Nest relationship of the Argentine ant, Iridomyrmex humilis (Hymenoptera: Formicidae). J. Kans. Entomol. Soc. 41: 511-516.

Markin, G. P. 1970. Food distribution within laboratory colonies of the Argentine ant, Iridomyrmex humilis (Mayr). Insectes Soc. 17: 127-158.
Perkins, R.C.L. 1913. Fauna Hawaiiensis. Cambridge-atthe-University Press, Cambridge, England.

Reimer, N. J., and J. W. Beardsley. 1990. Effectiveness of hydramethylnon and fenoxycarb for control of Pheidole megacephala (Hymenoptera: Formicidae), an ant associated with mealybug wilt of pineapple in Hawaii. J. Econ. Entomol. 83: 74-80.

Sokal, R. R., and F. J. Rohlf. 1981. Biometry, 2nd ed. Freeman, New York.

Tremper, B. S. 1976. Distribution of the Argentine ant, Iridomyrmex humilis Mayr, in relation to certain native ants of California: ecological, physiological, and behavioral aspects. Ph.D. dissertation, University of California, Berkeley.

Vander Meer, R. K., D. F. Williams, and C. S. Lofgren. 1982. Degredation of the toxicant AC 217,300 in Amdro imported fire ant bait under field conditions. J. Agric. Food Chem. 30: 1045-1048.

Ward, P. S. 1987. Distribution ofthe introduced Argentine ant (Iridomyrmex humilis) in natural habitats of the lower Sacramento Valley and its effects on the indigenous ant fauna. Hilgardia 55: 1-16.

Wilson, E. O., and R. W. Taylor. 1967. The ants of Polynesia. Pac. Insects Monogr. 14.

Received for publication 1 April 1998; accepted 27 August 1998. 